\title{
EFFECT OF EXOGENOUS POLYUNSATURATED FATTY ACIDS ON LIPOGENIC ENZYME ACTIVITY IN RAT LIVER UNDER FIXED CARBOHYDRATE CONSUMPTION
}

\author{
Yasutoshi Muto ${ }^{1}$, Naomi ShINOHARA ${ }^{2}$, Sermsri BANPHOtKaSEM ${ }^{3}$, \\ Noriko IITOYo, and Norimasa HosoyA \\ Department of Nutrition, School of Health Sciences, Faculty of Medicine, \\ University of Tokyo, Hongo, Tokyo
}

(Received December 24, 1974)

\begin{abstract}
Studies were conducted to evaluate specific dampening of hyperlipogenesis (i.e. enhanced lipogenic enzyme activity of the liver in rats refed a high carbohydrate, fat-free diet: F-diet) by exogenous polyunsaturated fatty acids under fixed carbohydrate consumption.

In force-feeding of rats with a linoleate-rich diet (F-diet containing $4.5 \%$ safflower oil), the lipogenic enzyme activities; fatty acid synthetase (FAS) and malic enzyme (ME), in the liver supernatant were found to be significantly lower than those in rats force-fed only an F-diet $(p<0.02)$, under conditions of identical consumption of carbohydrate. Among the various methylesters of unsaturated fatty acids administered by gastric intubation at a dose of $0.3 \mathrm{~g}$ per $100 \mathrm{~g}$ body weight, arachidonate was most potent in bringing about a significant reduction of hyperlipogenesis without seriously affecting food intakes.

During the same three-day experimental period, fatty acid GLC spectra in both the liver and plasma lipids reflected the exogenous input of PUFA. Plasma total fatty acid concentration (mainly triglyceride) significantly decreased in the arachidonate group $(p<0.01)$.
\end{abstract}

Recently, the nutritional role of essential fatty acids (EFA) can be re-evaluated since dairy products or meats fortified with linoleic acid are now available and have been found to be useful for achieving a lowering of plasma cholesterol and

1 武藤泰敏, 2篠原直美, ${ }^{3}$ セームシ・バンホトカセム，1飯豊紀子，1細谷憲政

2 Present address: Indiana University School of Medicine, Indianapolis, Indiana, U.S.A.

3 Visiting trainee under the O.T.C.A. Exchange Program. Present address: Department of Pediatrics, Ramathibodi Hospital, Bangkok, Thailand.

Abbreviations: FAS, fatty acid synthetase; ME, malic enzyme; G6PDH, glucose-6phosphate dehydrogenase; EFA, essential fatty acid; PUFA, polyunsaturated fatty acid; GLC, gas-liquid chromatography. 
triglyceride in man. NESTEL et al. (1) have demonstrated further that such a linoleate-rich diet plays a role in reduction of plasma cholesterol due to a concomitant enhancement of total sterol excretion into the bile. As to the lowering of plasma triglyceride by EFA, the mechanism of action remains to be elucidated.

The activities of the key enzymes catalyzing fatty acid synthesis in the liver change similarly as an apparent coordinate group in response to a variety of nutritional and hormonal manipulations (see Ref. 2). When animals are fasted for two days and then fed a high carbohydrate, fat-free diet (F-diet), the striking adaptive rise in the activity of the key lipogenic enzymes is associated with severe deficiency in linoleic and arachidonic acids of the liver lipids within several days $(3,4)$. These elevated lipogenic enzyme activities (hyperlipogenesis) can be lowered toward normal either by oral supplementation of F-diet with a physiological dose of EFA, being mixed with the diet $(3-5)$ or given separately by gastric intubation $(6,7)$ in young animals, or by linoleate-rich milk in developing mice (8).

However, GozuKara et al. (9) have recently reported that exogenous fatty acids seem to repress the synthesis of a single lipogenic enzyme (viz G6PDH) indirectly since there was a diminution of food (carbohydrate) intake in these experiments. This would be similar to an indirect effect of exogenous insulin on hyperlipogenesis by simply altering the appetite (10). The present study, therefore, was undertaken to re-examine the specific dampening of hyperlipogenesis by dietary PUFA under fixed carbohydrate consumption in rats, using liver FAS and $\mathrm{ME}$ activity as markers for the lipogenic enzyme set.

\section{METHODS}

Animals. Male Wistar-strain rats (Shiihashi Co., Tokyo) were maintained on a balanced chow diet (Oriental Fermentation Co., Tokyo) until an average body weight of 170 to $180 \mathrm{~g}$ was attained. Animals were kept in a cabinet under controlled lighting conditions (lights off at 8:00 and on at 20:00). Starvation or refeeding usually started at 10:00. Tap water was freely available.

Diets. A high carbohydrate, fat-free diet (basal F-diet) was prepared in this laboratory (Table 1). The liquid F-diet used in force-feeding with or without safflower oil was made up as follows; $100 \mathrm{~g}$ of the basal F-diet was mixed thoroughly with $60 \mathrm{ml}$ of a $0.3 \%$ methyl cellulose solution (Daiichi Pure Chemical Co., Tokyo), giving a total volume of $116 \mathrm{ml}$. This diet, therefore, contained $86 \mathrm{~g}$ of solids or $56 \mathrm{~g}$ of sucrose in $100 \mathrm{ml}$. Safflower oil (Saffola, Pacific Vegetable Oil Corp., San Francisco) was added to the diet, replacing an equivalent amount of cellulose, so as to give a final concentration of $4.5 \%(\mathrm{~F}+\mathrm{S}$ diet $)$.

\section{Experimental design}

Experiment 1, Force-feeding. Complete supply of nutrients was achieved by gastric intubation of the liquid F-diet with or without safflower oil over three days 
Table 1. Chemical composition of synthetic high carbohydrate, fat-free diet (basal F-diet).

\begin{tabular}{lc}
\hline Sucrose $(99.8 \%$ pure) & $64.9 \%$ \\
Casein (vitamin-free) $^{\mathrm{a}}$ & 23.4 \\
Salt mixture $^{\mathrm{b}}$ & 4.44 \\
Vitamin mixture $^{\mathrm{c}}$ & 1.11 \\
Avicel (cellulose powder) $^{\mathrm{d}}$ & 6.15 \\
\hline
\end{tabular}

a Nutritional Biochemicals Co., Cleveland, Ohio.

b Tanabe Pharmaceutical Co., Tokyo.

c The following vitamins were made up to $200 \mathrm{~g}$ by adding Avicel. ${ }^{\mathrm{d}}$ Vitamin A palmitate, $0.24 \mathrm{~g}$; vitamin $\mathrm{D}_{2}, 13.2 \mathrm{mg}$; vitamin $\mathrm{E}$ acetate, $2.7 \mathrm{~g}$; vitamin $\mathrm{K}_{4}$ diacetate, $68 \mathrm{mg}$; choline chloride, $12.0 \mathrm{~g}$; niacin, $1.2 \mathrm{~g}$; inositol, $6.0 \mathrm{~g}$; pyridoxine- $\mathrm{HCl}, 0.42 \mathrm{~g}$; thiamine- $\mathrm{HCl}, 0.42 \mathrm{~g}$; riboflavin phosphate, $0.42 \mathrm{~g}$; calcium pantothenate, $0.9 \mathrm{~g}$; biotin, $20 \mathrm{mg}$.

d Asahi Kasei Co., Tokyo.

following two days of starvation. Several preliminary trials were carried out to define the dose and frequency of force-feeding so that rats were able to gain body weight and display a large adaptive rise in the activity of lipogenic enzymes which was comparable to that obtained in feeding ad libitum. The following procedure was finally adopted; each freshly prepared liquid diet was delivered to rats through a polyethylene tube (outer diameter: $2.5 \mathrm{~mm}$ ) from a $10 \mathrm{ml}$ disposal syringe attached to the tubing. The total amount of $12.5 \mathrm{ml}$ per $100 \mathrm{~g}$ rat per day was given in divided doses at 10:00, 14:00 and 20:00. Accordingly, the amount of carbohydrate (sucrose) administered was approximately $7 \mathrm{~g}$ per $100 \mathrm{~g}$ body weight. This was found to be greater than the average amount consumed by rats fed $a d$ libitum $(5.8 \mathrm{~g} / 100 \mathrm{~g}$ body weight). A pretraining period was essential for getting rats accustomed to force-feeding. Twelve out of 20 rats were selected for Experiment 1.

Experiment 2, Ad libitum feeding with oil supplementation. Several methylesters of fatty acids; oleate, linoleate and arachidonate, were administered at a dose of $0.3 \mathrm{~g}$ per $100 \mathrm{~g}$ body weight through a stomach tube each morning over a refeeding period of three days following two days starvation. Powdered F-diet was freely accessible, and food intakes were carefully measured in individual rats every day during the entire experimental period (see Table 3). Each of the methylesters employed was greater than 99 percent pure: oleate and linoleate (Ono Pharmaceutical Co., Osaka), and arachidonate (Byron Chemical Co., Long Island City, New York). Major contamination in the arachidonate preparation was found to be 5,8,11,14,17-eicosapentaenoate $(20: 5, \omega 3)$.

Four or five rats were used in all experimental subgroups.

Enzyme and lipid analysis. On the fourth day at 10:00, animals were killed by decapitation, and blood was collected into a heparinized tube, from which plasma was immediately separated and frozen until analysis.

One portion of each liver was homogenized in two volumes of buffer con- 
taining $0.25 \mathrm{M}$ sucrose, $0.1 \mathrm{M}$ potassium phosphate buffer ( $\mathrm{pH} 7.4$ ), $0.07 \mathrm{M} \mathrm{KHCO}_{3}$, $1 \mathrm{~mm}$ EDTA, and $1 \mathrm{~mm}$ dithiothreitol. The soluble liver supernatant ("clear" sup), which was obtained by centrifuging the homogenate at $105,000 \times g$ for $60 \mathrm{~min}$, was used for determining the activity of FAS and ME spectrophotometrically.

The second portion of each whole liver, and plasma were used for analyzing fatty acid composition in the total lipid fraction. Lipid was extracted by the method of FoLCH et al. (11), containing hydroquinone $(10 \mathrm{mg}$ per $\mathrm{g}$ liver or $\mathrm{ml}$ plasma) and arachidic acid (Applied Since Lab., Inc.) as an internal standard (5 mg per $\mathrm{g}$ liver or $1 \mathrm{mg}$ per $\mathrm{ml}$ plasma). Each crude lipid extract was washed once by adding one-fifth volume of $0.2 \% \mathrm{HCl}$ solution. Methylation was accomplished with $2 \mathrm{ml}$ of redistilled methanol, containing $2 \% \mathrm{H}_{2} \mathrm{SO}_{4}$ under $\mathrm{N}_{2}$ gas overnight at $60^{\circ} \mathrm{C}$. The methyl esters were separated by GLC $(10 \%$ EGSS-X coated on Gaschrom P, column temperature $180^{\circ} \mathrm{C}$ ) using Shimadzu GC-6A. Identification of each peak was made from both relative retention time and carbon number as described by HOFSTETTER et al. (12).

\section{RESULTS}

\section{Experiment 1 (Table 2)}

Marked body weight gains were achieved by force-feeding during the three days of refeeding both the F-diet and the diet supplemented with safflower oil $(\mathrm{F}+\mathrm{S})$. On the average, $17.8 \mathrm{~g}$ weight gain was observed in the $\mathrm{F}$ group and $21.3 \mathrm{~g}$ in the $\mathrm{F}+\mathrm{S}$ group. Rats in $\mathrm{F}+\mathrm{S}$ group gained more $(+20 \%)$, although this difference is not statistically significant. On the other hand, activities of lipogenic enzymes; FAS and ME in the liver of $\mathrm{F}+\mathrm{S}$ group fell to significantly lower levels: $13.0 \mu \mathrm{moles} / \mathrm{min} /$ whole liver $/ 100 \mathrm{~g}$ rat $(-30 \%)$ and $35.8(-46 \%)$, respectively. This was true both on a basis of enzyme activity per whole liver per $100 \mathrm{~g}$ body weight and activity per mg protein of liver supernatant (or per $\mathrm{g}$ liver).

The total fatty acid concentration in the liver of $\mathrm{F}+\mathrm{S}$ group (on average, 73.8 $\mathrm{mg} / \mathrm{g}$ liver) was not significantly different from that of $\mathrm{F}$ group $(78.1 \mathrm{mg} / \mathrm{g}$ liver). However, the fatty acid spectra of the two groups were distinctly different: decreases in both 18:1 $(\omega 9)$ and 20:3 $3(\omega 9)$, and increases in both 18:2 ( $\omega 6)$ and 20: $4(\omega 6)$ were observed in F+S group. In particular, it was noted that the absolute concentration of $18: 2(\omega 6)$ was markedly elevated to $5.46 \mathrm{mg} / \mathrm{g}$ liver. The EFA index $(\omega 7+\omega 9 / \omega 6+\omega 3)$ was found to be significantly lower in $\mathrm{F}+\mathrm{S}$ group (1.85) in contrast to that in F group (4.93).

\section{Experiment 2 (Table 3)}

A suboptimal dose ( $0.3 \mathrm{~g}$ per $100 \mathrm{~g}$ body weight) was selected to afford a comparison of various methylesters of fatty acids without seriously affecting carbohydrate consumption. Average food intakes over an experimental period of three-days refeeding among the three groups were measured to be $28.9 \mathrm{~g}$ in oleate 
Table 2. Effects of force-feeding of carbohydrate with or without safflower oil on lipogenic enzyme activity and fatty acid composition in rat liver (Experiment 1).

\begin{tabular}{ccc}
\hline & Diet $\mathrm{F}$ & Diet $\mathrm{F}+\mathrm{S}^{\mathrm{a}}$ \\
\hline Body weight $(\mathrm{g})$ & $166.5 \pm 6.2^{\mathrm{b}}$ & $166.3 \pm 3.7$ \\
Body weight gain $(\mathrm{g}) \mathrm{c}$ & $17.8 \pm 2.3$ & $21.3 \pm 1.9$ \\
Liver weight $(\mathrm{g} / 100 \mathrm{~g}$ body wt.) & $5.4 \pm 0.4$ & $5.4 \pm 0.1$ \\
\hline Enzyme activity $(\mu$ moles/min/whole liver/100g body wt.) & \\
FAS & $18.7 \pm 1.7$ & $13.0 \pm 1.2^{* * \mathrm{~d}}$ \\
ME & $67.1 \pm 8.9$ & $35.8 \pm 6.8$ \\
\hline Total fatty acid & $78.1 \pm 16.4$ & $73.8 \pm 8.2$ \\
content (mg/g liver) & & \\
Fatty acid composition $(\%)$ & & \\
$14: 0$ & $1.4 \pm 0.3$ & $1.3 \pm 0.2$ \\
$16: 0$ & $31.9 \pm 1.2$ & $33.9 \pm 1.4$ \\
$16: 1(\omega 7)$ & $14.3 \pm 1.6$ & $11.0 \pm 0.7$ \\
$18: 0$ & $6.8 \pm 1.0$ & $8.3 \pm 0.3$ \\
$18: 1(\omega 9)$ & $33.3 \pm 2.1$ & $25.6 \pm 1.9^{* *}$ \\
$18: 2(\omega 6)$ & $2.3 \pm 0.4$ & $7.4 \pm 1.2^{* * *}$ \\
$20: 3(\omega 9)$ & $1.0 \pm 0.2$ & - \\
$20: 3(\omega 6)$ & $0.2 \pm 0.05$ & $0.6 \pm 0.2$ \\
$20: 4(\omega 6)$ & $5.2 \pm 1.3$ & $8.5 \pm 0.2^{*}$ \\
$20: 5(\omega 3)$ & $0.4 \pm 0.1$ & $0.6 \pm 0.05$ \\
$22: 5(\omega 6)$ & $0.5 \pm 0.1$ & $0.7 \pm 0.1$ \\
$22: 6(\omega 3)$ & $2.9 \pm 0.7$ & $2.3 \pm 0.2$ \\
\hline
\end{tabular}

a Two kinds of liquid diets; F, fat-free, and F+S, F-diet containing $4.5 \%$ of safflower oil $(55.4 \%$ linoleate) were given three times per day by a gastric tubing over three days to starved rats.

b Means \pm SEM.

c Body weight gain after refeeding for three days was indicated.

d T-test analysis was done in comparison with the $\mathrm{F}$ group, *, $p<0.05 ;{ }^{* *}, p<0.02$; $* * *, p<0.01$.

(control) group, $31.9 \mathrm{~g}$ in linoleate group $(+10 \%)$ and $25.2 \mathrm{~g}$ in arachidonate group $(-13 \%)$, respectively. The food intake in arachidonate group was found to be the lowest, although these differences are not statistically significant. In parallel with this experiment, additional information on food intakes was obtained using saline-treated rats (on average, $27.3 \mathrm{~g}$ ) and rats fed ad libitum (26.7 g), respectively. Therefore, neither gastric intubation nor oil feeding in itself seemed to affect the food intake (appetite) seriously.

Under these experimental conditions, both FAS and ME activity of the liver in arachidonate group were significantly decreased to $3.2 \mu \mathrm{moles} / \mathrm{min} /$ whole liver/ $100 \mathrm{~g}$ rat $(-68 \%)$ and $13.3(-73 \%)$, respectively. This was true regardless of the means for expressing enzyme activity (as previously mentioned). Moreover, the enzyme activity per unit weight of food intake was also found to be significantly 
Table 3. Effects of administration of polyunsaturated fatty acid methylesters on food intake, lipogenic enzyme activity and fatty acid composition in rat liver (Experiment 2).

\begin{tabular}{|c|c|c|c|}
\hline & \multicolumn{3}{|c|}{ Methylester } \\
\hline & Oleate (a) & Linoleate (b) & Arachidonate (c) \\
\hline Body weight $(\mathrm{g})^{\mathrm{a}}$ & $179.5 \pm 11.0^{\mathrm{b}}$ & $183.3 \pm 4.3$ & $174.0 \pm 8.7$ \\
\hline $\begin{array}{l}\text { Food intake } \\
\quad(\mathrm{g} / 100 \mathrm{~g} \text { b.w. })^{\mathrm{c}}\end{array}$ & $28.9 \pm 1.2$ & $31.9 \pm 1.9$ & $25.2 \pm 1.2$ \\
\hline $\begin{array}{l}\text { Liver weight } \\
(\mathrm{g} / 100 \mathrm{~g} \text { b.w. })\end{array}$ & $5.0 \pm 0.4$ & $5.1 \pm 0.2$ & $4.6 \pm 0.8$ \\
\hline \multicolumn{4}{|c|}{ Enzyme activity $(\mu \mathrm{moles} / \mathrm{min} /$ whole liver/100g body wt. $)$} \\
\hline FAS & $8.8 \pm 1.9$ & $8.8 \pm 1.5$ & $\begin{array}{c}3.2 \pm(.0 \mathrm{a})-\mathrm{c}) * \mathrm{~d} \\
\mathrm{~b})-\mathrm{c})^{* *}\end{array}$ \\
\hline ME & $49.7 \pm 1.1$ & $50.0 \pm 8.7$ & $\begin{array}{r}13.3 \pm 4.6 \text { a)-c)***** } \\
\text { b)-ce*** }\end{array}$ \\
\hline $\begin{array}{l}\text { Total fatty acid } \\
\text { content ( } \mathrm{mg} / \mathrm{g} \text { liver) }\end{array}$ & $47.3 \pm 3.9$ & $41.5 \pm 4.0$ & $31.2 \pm 8.2$ \\
\hline \multicolumn{4}{|c|}{ Fatty acid composition $(\%)$} \\
\hline $14: 0$ & $1.6 \pm 0.1$ & $1.5 \pm 0.2$ & $1.0 \pm 0.3$ \\
\hline $16: 0$ & $33.5 \pm 1.1$ & $32.3 \pm 0.8$ & $28.7 \pm 2.8$ \\
\hline $16: 1(\omega 7)$ & $11.4 \pm 0.4$ & $10.9 \pm 0.4$ & $5.5 \pm 2.6$ \\
\hline $18: 0$ & $8.7 \pm 0.9$ & $11.4 \pm 1.0$ & $16.5 \pm 2.8 \mathrm{a})-\mathrm{c})^{*}$ \\
\hline $18: 1(\omega 9)$ & $32.8 \pm 1.6$ & $25.4 \pm 0.6$ & $12.9 \pm 3.7 \mathrm{a})-\mathrm{b})-\mathrm{c})^{* * *}$ \\
\hline $18: 2(\omega 6)$ & $2.0 \pm 0.3$ & $5.6 \pm 0.3$ & $\begin{array}{c}3.0 \pm 1.1 \mathrm{a})-\mathrm{b})^{* * * *} \\
\mathrm{~b})-\mathrm{c})^{*}\end{array}$ \\
\hline $20: 3(\omega 9)$ & $1.7 \pm 0.1$ & $0.2 \pm 0.1$ & a)-b),c)**** \\
\hline $20: 3(\omega 6)$ & $0.1 \pm 0.03$ & $0.9 \pm 0.1$ & - a)-b),cc) ${ }^{* * *}$ \\
\hline $20: 4(\omega 6)$ & $4.9 \pm 0.7$ & $8.3 \pm 0.5$ & $25.0 \pm 4.0 \mathrm{a})-\mathrm{b})-\mathrm{c})^{* * *}$ \\
\hline $20: 5(\omega 3)$ & $0.4 \pm 0.1$ & $0.5 \pm 0.1$ & $1.6 \pm 0.3 \mathrm{a}), \mathrm{b})-\mathrm{c})^{* * *}$ \\
\hline $22: 5(\omega 6)$ & $0.4 \pm 0.1$ & $0.7 \pm 0.1$ & $\begin{array}{c}1.5 \pm 0.1 \mathrm{a})-\mathrm{c})^{* * * *} \\
\mathrm{~b})-\mathrm{c})^{* * *}\end{array}$ \\
\hline $22: 6(\omega 3)$ & $2.4 \pm 0.4$ & $2.6 \pm 0.1$ & $4.5 \pm 1.3$ \\
\hline
\end{tabular}

Rats were refed F-diet ad libitum after $48 \mathrm{hr}$ starvation, and various kinds of methylesters such as oleate, linoleate and arachidonate were simultaneously given at a dose of $0.3 \mathrm{~g} / 100 \mathrm{~g}$ b.w. by a gastric tubing once every morning over three days of refeeding.

a Final body weights were indicated here.

b Means \pm SEM.

c Food intake and body weight were measured every day over a three day experimental period, and then expressed as an average food intake on the basis of $100 \mathrm{~g}$ body weight.

d T-test analysis; *, $p<0.05$; **, $p<0.02$; ***, $p<0.01$; ***, $p<0.001$.

reduced in arachidonate group. Both FAS and ME activity in saline-treated rats remained at the control level of 8.9 and $57.8 \mu \mathrm{moles} / \mathrm{min} /$ whole liver $/ 100 \mathrm{~g}$ body weight, respectively.

The total fatty acid concentration in the liver of arachidonate group was found to be lower (on average, $31.2 \mathrm{mg} / \mathrm{g}$ liver), although this value is not statistically significant in comparison with those in the other two groups. However, relative 
fatty acid composition of each group was quite heterogeneous, since they reflected the exogenous input of methylesters: viz 18:1 $(\omega 9)$ and 20:3 ( $\omega 9)$ were markedly decreased in rats fed EFA, particularly arachidonate. On the other hand, administration of linoleate brought about a significant increase in 20:4 $(\omega 6)$ as well as 18:2 $(\omega 6)$ itself. The highest value of $20: 4(\omega 6)$, however, was obtained in the arachidonate fed group $(25.0 \%$ or $7.8 \mathrm{mg} / \mathrm{g}$ liver) without any increase in $18: 2(\omega 6)$. Each EFA index in the liver was calculated to be 4.74 in the oleate, 1.98 in the linoleate and 0.66 in the arachidonate group, respectively.

Each fatty acid spectrum in the plasma was found to be very similar to that in the liver, although the total fatty acid concentration in the arachidonate group $(1.07 \mathrm{mg} / \mathrm{ml})$ was significantly decreased $(p<0.01)$.

\section{DISCUSSION}

It has been well established that ingestion of carbohydrate induces the net synthesis of a lipogenic enzyme set in the liver (see Ref. 2). Furthermore, Holten's group $(9,10)$ reported that induction of lipogenic enzyme seems to be correlated only with the amount of carbohydrate intake above a threshold (which has been estimated by SHINOHARA (5) to be approximately $4 \mathrm{~g}$ or $16 \mathrm{kcal}$ of sucrose/100g $\mathrm{rat} / 40 \mathrm{hr}$ on refeeding following two days of starvation). The present study has focused on examining whether or not dietary fat, specifically methylesters containing PUFA, has a selective dampening effect on hyperlipogenesis under conditions of fixed carbohydrate consumption. For this purpose, the authors first adopted a force-feeding procedure which seemed to be superior to pair-feeding of rats. As shown in Table 2, marked weight gains and increases in lipogenic enzyme activities; FAS and ME, were achieved when starved rats were refed F-diet by force-feeding for three days. Force-feeding of the F-diet, however, required more carbohydrate (calories) than that in ad libitum feeding, although no clinical signs of malabsorption (diarrhea and/or indigestion) were seen in these rats. In any event, a significant reduction of FAS and ME activity was observed by the addition of safflower oil, containing $55.4 \%$ linoleate, even though the carbohydrate intake in the two series was identical. Hence, it is concluded that dietary fat containing PUFA can play an important role in dampening hyperlipogenesis in rat liver.

The above-mentioned result prompted us to investigate what kinds of acyl moiety would be the most potent in this kind of regulation of lipogenesis in rat liver. However, no successful pilot experiments were obtained by force-feeding of F-diet supplemented with individual methylesters of unsaturated fatty acids, mainly because of technical problems; a marked enlargement of the stomach (indigestion) during two days of refeeding. Thus, suboptimal doses were selected for a comparison of various methylesters in an experiment that involved simultaneous measurements of food intake, in order to evaluate effects of exogenous PUFA on hyperlipogenesis in rat liver. In Experiment 2, arachidonate was found to be 
the most potent with respect to a reduction of lipogenic enzyme activities, despite a slight decrease in food intake which in itself was not statistically significant. Moreover, the relative as well as the absolute concentrations of 20:4 ( $\omega 6)$ were

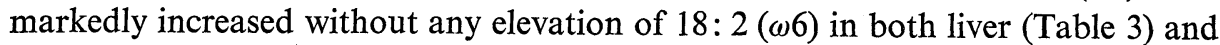

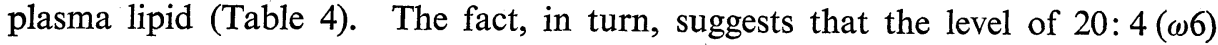
in liver lipid is much more responsible for reduction of hyperlipogenesis than that of 18:2 $(\omega 6)$. On the other hand, administration of linoleate had little effect on lipogenic enzyme activity in Experiment 2, despite a similar dose of linoleate given in comparison with that in Experiment $1(\mathrm{~F}+\mathrm{S}$ group). This discrepancy between Experiment 1 and 2 remains to be elucidated. Only an explanation for this, however, can be made from the absolute concentration of 20:4 ( $\omega 6)$ in liver lipid: the level in the linoleate group, Experiment $2,(3.4 \mathrm{mg} / \mathrm{g}$ liver $)$ was found to be lower than that in the $\mathrm{F}+\mathrm{S}$ group, Experiment $1,(6.3 \mathrm{mg} / \mathrm{g}$ liver $)$ and much lower than that in the arachidonate group $(7.8 \mathrm{mg} / \mathrm{g}$ liver).

In contrast to triglyceride, dietary free fatty acid or its methylester seems to cause severe growth retardation in the chick (13). Therefore, the arachidonate effect obtained here warrants further exploration. In particular, a micellar preparation of triglyceride or monoglyceride containing pure arachidonate would be ideal for this purpose. Moreover, absorption of carbohydrate and/or insulin secretion from the pancreas in the presence of PUFA remains to be investigated further under fixed carbohydrate consumption.

In any event, dietary triglyceride containing PUFA should be tried for inhibiting or repressing hyperlipogenesis in the liver. Dietary PUFA brings about a significant decrease in plasma triglyceride, probably as a result of the reduced lipogenesis from carbohydrate in the liver (Table 4).

Table 4. \% Fatty acid composition of total lipid in rat plasma (Experiment 2).

\begin{tabular}{|c|c|c|c|}
\hline & \multicolumn{3}{|c|}{ Methylester } \\
\hline & Oleate (a) & Linoleate (b) & Arachidonate (c) \\
\hline $14: 0$ & $1.2 \pm 0.1^{\mathrm{a}}$ & $1.3 \pm 0.9$ & $0.8 \pm 0.1$ \\
\hline $16: 0$ & $28.8 \pm 0.8$ & $28.7 \pm 1.5$ & $29.1 \pm 0.9$ \\
\hline $16: 1(\omega 7)$ & $10.8 \pm 2.2$ & $12.7 \pm 1.7$ & $9.2 \pm 0.7$ \\
\hline $18: 0$ & $11.8 \pm 0.7$ & $13.0 \pm 0.7$ & $\begin{array}{r}16.1 \pm 1.2 \text { a)-c)***} \\
\text { b) }-\mathrm{c})^{* * b}\end{array}$ \\
\hline 18: $1(\omega 9)$ & $35.2 \pm 1.5$ & $21.9 \pm 0.1$ & $12.9 \pm 1.1$ a)-b)-c)**** \\
\hline $18: 2(\omega 6)$ & $4.6 \pm 1.1$ & $10.6 \pm 1.1$ & $\begin{array}{r}2.2 \pm 0.5 \text { a) }-\mathrm{b})^{* * *} \\
\text { b) }-\mathrm{c})^{* * * *}\end{array}$ \\
\hline $20: 3(\omega 9)$ & $2.3 \pm 0.5$ & $1.2 \pm 0.2$ & - $\quad$ a)-b),c)*** \\
\hline $20: 3(\omega 6)$ & $0.5 \pm 0.1$ & $1.1 \pm 0.1$ & - \\
\hline $20: 4(\omega 6)$ & $4.9 \pm 0.8$ & $10.3 \pm 0.8$ & $\begin{array}{l}29.7 \pm 1.6 \text { a)-b)*** } \\
\text { b)-c), a)-c) } * * * *\end{array}$ \\
\hline Total fatty acid (mg/ml) & $1.92 \pm 0.04$ & $1.61 \pm 0.5$ & $1.07 \pm 0.2 \mathrm{a})-\mathrm{c})^{* * *}$ \\
\hline
\end{tabular}


The authors are grateful to Professor David M. Gibson, Department of Biochemistry, Indiana University School of Medicine, Indianapolis, for his continued, warmful advice and encouragement throughout this study.

\section{REFERENCES}

1) Nestel, P. J., Havenstein, N., Whyte, H. M., Scott, T. J., and Cook, L. J., New Engl. J. Med., 288, 379 (1973).

2) Gibson, D. M., Lyon, R. T., Scott, D. F., and Muto, Y. Adv. Enzym. Regul., 10, 187(1972).

3) Allmann, D. W. and Gibson, D. M., J. Lipid Res., 6, 51 (1965).

4) Allmann, D. W., Hubbard, D. D., and Gibson, D. M, J. Lipid Res., 6, 63 (1965).

5) Shinohara, N., Dissertation (Master of Science Degree), Indiana University School of Medicine (1971).

6) Muto, Y., and Gibson, D. M., Biochem. Biophys. Res. Comm., 38, 9 (1970).

7) Chu, L. C., McIntosh, D. J., Hincenbergs, I., and Williams, M. A., Biochim. Biophys. Acta, 187, 573 (1969).

8) Smith, S., and Abraham, S., Arch. Biochem. Biophys., 136, 112 (1970).

9) Gozukara, E. M., Frolich, M., and Holten, D., Biochim. Biophys. Acta, 286, 155 (1972).

10) Rudack, D., Chisholm, E. M., and Holten, D., J. Biol. Chem., 246, 1249 (1971).

11) Folch, J., Lees, M., and Sloane-Stanley, G. H., J. Biol. Chem., 226, 497 (1957).

12) Hofstetter, H. H., Sen, H., and Holman, R. T., J. Am. Oil Chem. Soc., 42, 537 (1965).

13) BRAmbila, S. and Hill, F. W., J. Nutr., 88, 84 (1966). 